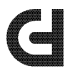 \\ COUNTERFUTURES \\ Left thought \& practice Aotearoa
}

\section{THREE}




\title{
No Pride in Prisons on Abolitionist Politics
}

\author{
Interview with Emilie Rākete, Ti Lamusse and \\ Sophie Morgan
}

ATE LAST YEAR, Warwick Tie spent time with members of the queer and transgender activist collective No Pride In Prisons to learn how penal politics had become, for them, a site of radical activism. Those members are Emilie Rākete, Ti Lamusse and Sophie Morgan.

Warwick Tie

Tell me about how the collective took on the work of prison abolition. ${ }^{1}$

1 Since this interview was conducted, No Pride in Prisons decided to become a broad-based prison abolitionist organisation. Membership is now open to anyone who supports the kaupapa of the organisation. 


\section{Emily Rākete}

There is no single point at which we can say No Pride in Prisons began, however the story of No Pride in Prisons usually begins with the 2015 Pride parade. When we saw that there were going to be cops and Corrections officers marching in the 2015 Pride parade, a group of us who were already organising together on other issues decided we had to stop that from happening. Three of us decided to jump onto Ponsonby Road and try to stop the Police float from progressing. At this point, we had not yet solidified as a group known as 'No Pride in Prisons'. In a sense, No Pride in Prisons came about as a result of our reaction to what we saw as a queer collaboration with the prison system, and our name specifically responded to that collaboration but also more broadly the criminal injustice system.

\section{WT}

It sounds like collaboration was occurring explicitly between the Pride organisers and the prison system.

\section{Sophie Morgan}

Yes, between the Pride Parade organisers and Corrections. 2015 was the first year Police and Corrections officers were invited to march in Auckland Pride. So we saw that as collaboration, in the sense that Auckland Pride took no issue with the harmful and oppressive institutions that those officers represented-it'd rather be a vehicle for said institutions to celebrate the sexual diversity of their staff. We were concerned by that, and it was under those circumstances, particular to Auckland Pride, that we became a specifically queer and trans prison abolitionist group. I don't think we ever said, 'right, so we're going to have a prison abolitionist organisation, and it's going to be made up only of queer and trans people, and we're only going to deal with queer and trans issues'. I don't think that was ever really a conscious 
decision on our part. It sort of emerged because of the situation with Auckland Pride and our politics at the time.

\section{Ti Lamusse}

I want to highlight the thought that went into our initial action and into our formation as a queer and transgender prison abolitionist organisation. The way that I was thinking at the time was that the prison is a specific site of intervention that gives us an opportunity to attack certain forms of power that do damage to certain communities. Although it does damage to all communities, it does damage to certain communities more than others. For queer and trans people organising in various movements and organisations seeking things as broadly as post-capitalism, queer and trans liberation, women's liberation, and decolonisation, among other things, we saw the prison as a place in which all these struggles intersect, as a point of alliance. We could see how Māori are being fundamentally oppressed by prison, and, at the same time, that the experience of incarceration for queer and transgender people is one of constant humiliation, constant threat of sexual and other violence. As people seeking to build a movement and to overthrow those institutions which are oppressing us, the prison is a necessary point of coming together where we can form solidarity with one another, even if we don't have exactly the same life experiences or even necessarily exactly the same politics. Prison abolitionist politics is a political space where our mutual relation to domination gives us the opportunity to fight together.

\section{WT}

What does it mean to 'see' that point of intersection? What was happening that enabled that site to come into view? 


\section{SM}

I think we were pretty heavily influenced by other, pre-existing organisations. We've worked a little bit with Against Equality in the past, another queer and trans prison abolitionist project. Against Equality releases books, gives talks, among other things, and we worked with them in the early days of No Pride in Prisons when one of its members stayed with us and gave a seminar on queer liberation and prison abolition. We've also been heavily influenced by an organisation based in the US, ${ }^{2}$ called Black and Pink, which is also a queer and trans prison abolitionist organisation. Black and Pink conducted the largest survey ever of LGBT prisoners in the US, which has had a substantial impact on our advocacy and kaupapa. I would say No Pride in Prisons hugely depends on the thought and organising that's already been done, including the people who continue to work alongside us.

\section{ER}

I strongly urge you to watch a video from 1973 of Sylvia Rivera at the Christopher Street Pride parade. ${ }^{3}$ This video, along with many other artefacts from a forgotten radical queer history, shows that there is a history of using Pride to yell at other queers for their shit politics. This idea has been there from almost as soon as the idea of Pride existed, if not before. I think, even in the lead up to our first ever action as No Pride in Prisons, the idea that Pride was a riot, or that Pride should be a riot, dominated our thinking.

2 Lydon, Jason, Kamaria Carrington, Hana Low, Reed Miller \& Mahsa Yazdy, 'Coming out of Concrete Closets: A Report on Black \& Pink's National LGBTQ Prisoner Survey', Black \& Pink, 2015.

3 Calpernia, 'Trans Activist Sylvia Rivera at the 1973 Christopher Street Liberation Day rally', YouTzube, 7 April 2014. 
WT

And you thought to recapture something about that notion of Pride as a riot?

\section{SM}

When we started this conversation, we talked about the Auckland Pride Board's collaboration with Police and Corrections officers. This collaboration is basically to be expected, given liberal democracy, but it is also ironic, given any sense of the history of Pride. Pride started as a commemoration of a riot against Police, against the Police brutality at Stonewall Inn. It's crucial for us to be speaking back to that history so that we can stand here now and say, 'here is how Pride started and here is how Pride is now-isn't there something wrong with these developments? Why should queers openly support these institutions? Why should Pride Parades become parades for corporations, banks, and politicians to display how rainbow-friendly their latest policies are?'

\section{WT}

It sounds like you saw the celebration of diversity for diversity's sake becoming inseparable from a commercialisation of gay pride.

\section{SM}

Yes, exactly.

\section{WT}

So you became an abolitionist movement. Why abolitionism rather than reform?

\section{ER}

For me, abolition stems from my decolonial politics. There is no precedent for the use of incarceration in tikanga Māori, and the 
only reason the New Zealand state has the ability to use prisons is that it militarily suppressed tino rangatiratanga during its invasion of Aotearoa. I don't see a clear distinction between the violence of the Musket Wars, which were British proxy warfare, the Land Wars, which were open imperialism by the British and New Zealand states, and the present era of violence, which operates through bio- and necropolitical institutions such as the prison. There is no historical point where we can say, up until here, what was happening was violent invasion, and then, after that, it was 'merely' the legitimate application of state power. Rather, the genocide of the Land Wars and the present system of police, juridical, and carceral discrimination are one continuous process. We are still living in an era of colonial violence, and so my politics against colonialism call on me to be a prison abolitionist.

\section{SM}

Obviously No Pride in Prisons is ultimately a prison abolitionist organisation, so we in no way settle on reforms. For me, it's because the prison is a very recent historical invention, which has disrupted more comprehensive community-based approaches to addressing harm. The prison's primary function has always been to facilitate repression and maintain political and economic relations, rather than to keep people safe. Angela Davis, for one, draws a clear line in her book Are Prisons Obsolete? between the legacy of chattel slavery in America, to the American prison system and its continuation of slavery. ${ }^{4}$ Davis argues that the prison has always been a repressive tool, particularly used against occupied indigenous people and the working class.

But even if we recognise the inherent violence of the prison and the necessity of abolition, in order to be sensible 
abolitionists, we cannot completely disregard reforms. This is something that we've displayed in the book we recently published, Abolitionist Demands: Toward the End of Prisons in Aotearoa. In that book, we have our short-term demands, our intermediateterm demands, and our long-term demands. Our long-term demands are the revolutionary demands we're ultimately working towards, like abolishing the colonial bourgeois state of New Zealand, implementing tikanga Māori, implementing transformative justice. Our short-term and intermediateterm demands are reforms, but are always geared towards decarceration and decriminalisation. These are all either a necessary step towards abolition, or they would improve the lives of incarcerated people, without expanding the prison industrial complex. So we do propose some reforms, but those reforms are what Davis calls 'abolitionist reforms'. Of course, we by no means stop at that, and we don't consider reform to be enough, because our analysis of the prison recognises its inherent violence.

TL

I'm going to try to draw together this question and the previous one. In terms of why prison abolition is important to myself and many others, I certainly support everything Emmy and Sophie have said. I would also like to add that, for me, prison abolition is appealing because it deals with the very seriousness of the situation as it currently stands, of the world that we're currently living in and attempts to address the roots of harm. Prison abolitionism, in order to be truly abolitionist, must extend well beyond the prison walls and grapple with issues such as wage exploitation, structural racism, and violence against women. All of these structures of oppression are inseparable from the way we deal with social harm, and the way we address people and communities when harm is done to them, as well as when they do harm. Prison abolition is a necessary step towards building a 
better way of organising ourselves and a more just world that's not based on necessary exploitation of workers, because I see the prison as one of the ways in which capitalism reproduces itself, or mediated through structural racisms, sexisms, and other forms of oppression.

Prisons fail to address very serious harm that has been done to us and that we do to others. Instead, it locks people away, puts those people who have done harm at even greater risk of violence, and, if anything, it makes them more likely to engage in violence later in life. If we want to be serious about changing harmful behaviours, if we want to be serious about building a better world for ourselves and for those who come after us, then we do need to pick up the fight that's already happening. We need to build better ways of dealing with harm, and I think prison abolition is a necessary step to a better world.

\section{WT}

If I can recap, then, on what's just been said .... It sounds like there are at least three different ways of thinking about abolition that run through No Pride in Prisons at the moment. One is that it's a fundamental element of decolonisation; another is that the reforms can speak to harms that have been visited on inmates; and then the other is a symbolic one-I think it's Angela Davis who said that we have prisons so we don't have to think about our policy failures. ${ }^{5}$ In terms of organising-and I'm thinking not just within No Pride in Prisons, but No Pride in Prisons in relation also to other abolitionist movementsto what extent do the approaches need to be coordinated, or is there a virtue in there being a number of different ways of thinking about abolition? 


\section{ER}

I don't think there's a disconnect between the things these two have said just now and what I said about abolition as decolonisation. Manuel De Landa has a model, adapted from Sun Tzu, which he uses to describe military conflict, which I use to think about political organising. There are three layers to the model, each one on a broader scale than the last. The first and narrowest is tactics - the science of assembling bodies in such a way as to win a battle. The second is strategics-the science of assembling battles in such a way as to win a war. The final is logistics-the science of assembling the resources necessary for the other two layers to even be possible. Sophie spoke about the tactical, making demands which strain at the limits of what the system can allow as a means of pushing for abolition. Ti and I spoke about strategic and logistical approaches to ensuring our demands build on actually-existing tendencies, and to ensuring that our politics respond materially to the historical situation in which we exist. On all three stages of De Landa's model, we're working to address the problem of the prisons, of military violence by the New Zealand state, and of the oppression of the working class by capital. I don't think that there's ever been much difficulty in coordinating across the different things we've all spoken about.

\section{TL}

I think there is certainly something to be said about basing an abolitionist politics on the specificity of our current situation. In Aotearoa, it requires basing our abolitionist politics on the understanding that prisons are in breach of tikanga Māori and stand in fundamental contradiction to tino rangatiratanga. That's where we start in our current context. I also agree with Emmy in terms of where we go from that starting point. Although No Pride in Prisons employs various logics and various ways of arguing the necessity of prison abolition, those logics and modes of argumen- 
tation aren't in conflict. However, I think that there are potentially arguments for abolition which are conservative, and which are not ultimately going to lead to a better situation for those who are currently experiencing the violence of the prison, and the prison as it extends beyond the walls. They are the kind of arguments that are based on fiscal necessity. ${ }^{6}$ They sound something like "prisons are so expensive, there must be some other way that we can deal with these horrible people who do these horrible things'. This kind of argument lends itself to a situation where, instead of having people in prisons, you have thousands more people on home detention, wearing ankle bracelets or under constant supervision. I would reject this kind of logic, as all it does is extend out the "carceral archipelago"7 so that it's affecting more people, in a more dispersed way.

\section{SM}

In a less obvious way and in a less targetable way.

\section{$\mathrm{TL}$}

Yes, exactly. That is where we would run up against a logical dispute between those logics of a conservative quasi-abolition and the vision of abolition which No Pride in Prisons promotes. Ours is an aspirational vision, one in which we don't just want to see the end of prisons, but we want to see a fundamental reshaping of the world so that prisons are no longer 'necessary'.

\section{ER}

There's a quip that we use sometimes: the solution isn't better pris-

6 Ti was referencing the now infamous quotation from the Finance Minister Bill English that prisons are 'a moral and fiscal failure'. Bill English, ' 50 Key Thinkers Forum: Deputy Prime Minister Hon Bill English', Lecture, Families Commission, New Zealand, 11 May 2011.

7 Michel Foucault, Discipline and Punish: Birth of the Prison, trans. Alan Sheridan, New York 1995. 
ons, or better incarceration, or better management technologies, but less of all of those things. So, not 'less prisons, more ankle bracelets' or 'less prisons, more lethal injections', but simply less domination.

\section{SM}

Because it's that punitive approach to social harm that is one of the key issues with the prison. It's not like we would advocate for a society which, say, practised public torture instead of incarceration. It's the vengeful politics and logic behind the prison which is the problem. So again, as Ti was saying, having someone with an ankle bracelet on, which binds them to a certain radius around their house, is still a situation in which you've got them on lockdown and you're restricting their freedom of movement. That's still carceral, so we would fundamentally reject it. There are some other ideas that have been thrown around, such as building prisons specifically for trans people, which is something that we as an organisation categorically oppose. The answer to this issue is not to put trans people in a nicer prison, all together, segregated for some reason from all other incarcerated people. The answer is organised decarceration. We don't want to be building more prisons, we want to be stopping prison construction from happening.

\section{WT}

The way you talk about abolitionism sounds very utopian. I don't mean that in a pejorative sense, but my question is: what sense do you have about the resurgence of utopian thought? It can be criticised for being unrealistic. But utopianism has again become a way by which the left can imagine alternative futures. What is required in order for utopian thought to succeed?

TL

I'm hesitant to use the word 'utopian', but that may just be for 
semantic reasons. What I would define as utopian is a future or vision for the future which is ungrounded and is not based on the material conditions at hand. A political future I would want to see would be one which looks at where we are now, and uses our material conditions as they currently stand to build to something better. So it's something like using levels of automation at work to fundamentally reduce the amount of work we have to do. In terms of abolition, it includes looking at already existing strategies for dealing with harm that various communities have adopted in the past, and continue to use today, and learning from actually existing strategies that are alternatives to prisons. I think there's a lot of work that needs to be done on the Left in terms of making this link between where we are now and where we can go, as long as where we can go is aspirational, and is hopeful, and will be a fundamental change from where we are now. This requires using where we are now as a starting point.

\section{SM}

Similar to Ti, I prefer scientific thought to utopian thought. No Pride in Prisons is an anti-capitalist organisation and is therefore heavily influenced by Marxist thought. I think that any analysis of the prison needs to always be grounded in the material political and economic situation, and therefore in historical materialism. So I think we can sometimes frame it in a way that's sort of utopian, perhaps for rhetoric's sake, or perhaps because sometimes that speaks a little more to people. You tend not to get an overwhelming response if you say 'the dialectical science of the vanguard', so of course we phrase ourselves differently. But I do think that an effective prison abolitionist analysis must be grounded in, as Ti was explaining, an analysis of the material situation and of how the material situation has developed historically. 


\section{WT}

How does that work out in No Pride in Prisons then? What happens in the life of No Pride in Prisons that it allows that kind of analysis to emerge?

TL

There are some of us, myself included, who are doing research into prisons. This research constantly flows back into the organisation, and influences our actions and our ways of thinking. In addition, our experiences with the incarcerated people that we work with always impacts the way in which we view things, and the tactics that we use. We are constantly updating our analysis as things change. I hope we are doing so in a scientific manner.

\section{ER}

I think our use of the Official Information Act has been really influential in this regard. I don't think before we started doing those, that people had necessarily such a clear idea of the material situation for prisoners. I looked on fyi.org and it appears that at least a third of all the questions for Corrections are from No Pride in Prisons. There's been a lot of information coming out of them, and it's been really helpful just to understand the magnitude of the problems. To hear it straight from the sexual abusers' mouths just how many strip searches its doing was astonishing. I certainly didn't suspect the magnitude of how many completely unnecessary strip searches were being conducted until we actually got those numbers.

\section{TL}

That is a really good example of where we are consistently doing materialist analysis. About four years ago, Alex Harris submitted an Official Information Act request on the number of 
strip searches. ${ }^{8}$ I stumbled across it about a year ago and I was shocked, first, by how many strip searches were conducted and then, second, by the fact that $99.76 \%$ of strip searches at that time found absolutely no contraband whatsoever. ${ }^{9}$ Therefore, hundreds of thousands of strip searches were being conducted on prisoners for no clear reason. Fast forward four years and I submit another request on strip searches. From the updated information in that request, we see that the total number of strip searches has reduced substantially, but the amount of contraband that was found has barely changed at all. ${ }^{10}$ The data shows that for decades the Department of Corrections was conducting millions of strip searches on people which it knew was pointless, in terms of finding contraband. Even with the reduction in the total number of searches, $99.51 \%$ of all strip searches still led to no contraband being found in 2014/2015.

When we talked to incarcerated and formerly incarcerated people about this, they consistently told us of the humiliation and invasiveness of the searches. When the statistical analysis of the number of searches are combined with the qualitative analysis of people's experience of being searched, we came to the conclusion that strip searches are a regularised form of sexual assault. It is highly unlikely that a person would otherwise consent to having someone in a position of authority, a stranger, strip them naked, get them to bend over, squat naked,

8 Jeanette Burns, 'Number of strip searches carried out per year', FYI.org.nz, accessed 12 December 2015, https:/fyi.org.nz/request/185/response/2552/attach/ html/3/ Response\%20sent..PDF.pdf.html.

9 Of the 208,661 strip searches conducted between 1 July 2010 and 30 June 2011, only 511 resulted in contraband being found.

10 The total number of searches between July 12014 and June 302015 fell to 115,166 . The total number of searches resulting in contraband finds was relatively steady at 472 . The data Ti requested has been analysed in this NZ Council for Civil Liberties blog post: Mark Hanna, 'Guest post: Strip searches in prisonswhat is reasonable?' NZ Council for Civil Liberties, accessed 5 July 2016, https:// nzccl.org.nz/blog/guest-post-strip-searches-prisons-what-reasonable. 
fiddle with their genitals, rub their hair, all of which is allowed under the Corrections Act. There is no way that would happen were it not for them being in prison. We should see this for what it is: routinised sexual assault by Corrections officers. This the kind of analysis that we're committed to doing as an organisation.

Perhaps I should add one caveat to what I just said. I do think people, obviously incarcerated people and perhaps their whānau, are aware that this is going on and that's its a problem, but what I hope we've been able to do is to demonstrate for the broader public the seriousness of the situation. I hope that, with an abolitionist analysis, we have shown that strip searches are a fundamental practice to a prison, not in order to find contraband, because it doesn't really do that, but in order to maintain domination over and the dehumanisation of prisoners.

\section{ER}

And just to keep pumping on about strip searches, there's this argument that we often get like 'well, what do you expect them to do? You can't run a prison and not strip search people'. That's an argument for abolition, fundamentally. If the situation there is so awful that you need to rape people to make sure that they're not going to stab you, then that environment needs to be completely changed.

\section{SM}

If people are in a situation in which they feel so unsafe that it would be totally understandable for them to fashion a shank out of a toothbrush then maybe we need to be reconsidering the situation.

\section{WT}

It sounds like findings such as these are strengthening your general criticism of incarceration. On the other side of things, what 
do you feel are the major challenges that face the abolitionist movement at the moment?

\section{SM}

I'd say the major challenge for abolitionist movements, first and foremost, are the material conditions; the fact that we live in a capitalist, 'post-colonial' epoch and that the prison, regardless of whether or not it could be used beyond the colonial, capitalist society, has very much been fashioned to be integral to that society's maintenance. For us, prison abolition is part of a larger programme of political and economic revolution, so the primary challenge is overcoming our current material conditions and the structures that maintain them. I think the second challenge, particularly concerning the ideological situation in Aotearoa, is a kind of penal populism. There's a law lecturer at Auckland University, Warren Brookbanks, who has researched and written on the implementation of 'Three Strikes' legislation in New Zealand. He argues that the legislation has been pushed through because of politicians taking advantage of 'penal populism', or the public's punitive sentiments. New Zealand does seem to foster an exceptional culture of carceral politics and distaste towards people classed as criminal, and I wouldn't be able to speak to where exactly that comes from.

\section{WT}

It sounds like our shared attachment to punishment is one of those biggest challenges?

\section{SM}

Yeah, absolutely.

ER

I think this is demonstrated perfectly by something that's domi- 
nating the news as we speak. The Wellington rugby player Losi Filipo was discharged without conviction for assaulting a group of people. Absolutely, he did something wrong; he caused serious social harm. The response has been an enormous feminist outcry of 'lock him up, lock him up, you should definitely put him in prison'-to, well, to do what? Are we to believe that putting him in prison, where violence is inescapable, will help him learn that violence is wrong? There's a certain kind of laziness in how we think about how to deal with these issues, when we've had almost two unbroken centuries of this government and this government's predecessor putting brown people in jail. I feel like after a hundred and twenty-five years of incarceration not achieving the purpose we are told it is for, we either need to accept that we need to do something else to achieve what we are told incarceration is for, or accept that incarceration is for something other than what we've been told it's for.

And the reality is that prisons are not for correcting social harm. They are for maintaining state control. The New Zealand government's constitutional sovereignty was only achieved through bloodshed, and, as part of its desperate struggle to maintain that sovereignty, it has had to fight innumerable wars up and down these motu, against almost every Māori collective that exists. It has had to militarily crush our resistance to its claims to be able to legislate. The prison, as I said before, is the contemporary form that that military conflict has taken. Nearly one percent of the Māori population is in prison. Those are prisoners of war. Every prisoner is a political prisoner, and I don't want to claim an elevated particularity just for Māori, but the use of prisons against Māori is a military tactic used by the state against the rangatiratanga of our people.

The point is to destroy our ability to organise politically, to tear apart our communities so that they cannot resist the imposition of colonialism. I think understanding New Zealand 
as an ongoing military occupation has been a really important part of determining what the prison is for, and understanding that it's one among a number of military technologies used to maintain that occupation. It's not just a matter of saying 'well, beneficent state, you have tried prisons to correct rugby players hitting women. But alas it has not functioned and so, in your infinite wisdom, please use a different technology'. Because the state was never using prisons to try to make sure that rugby players don't hit people. The state was making sure that no one cuts down any flagpoles, making sure that no one builds a wharenui on Takaparawha. The state needs to dominate the working class, to maintain bourgeois control of production, to repress any expression of mana motuhake. I don't think that we can understand the prison as a failed corrective technology. I don't think that's what it is. It certainly appears as one, and to point out the ways in which it is not is an important way of attacking it.

\section{WT}

We could bring our time together to a close with your reflections on the challenges facing abolitionism.

\section{TL}

I think what Emmy and Sophie said is absolutely correct-that we can't separate the prison from the social system and the historical conditions that brought it into existence, and that the prison is an incredibly important repressive apparatus. What I'm particularly concerned with at the moment is how we have apparently abandoned the humanity of prisoners, and the way this is inflected through racism and through class-based oppression. This means that when harm is done to prisoners, we can't recognise that harm as being harm, because the prisoner is not seen as a human. An example of this would be strip searches. As I argued 
before, strip searches are a routinised, regularised form of sexual assault. For many people, this regularised sexual assault would not be seen as an issue because, according to a normative standard, the body that is being humiliated and dehumanised is not seen as a human body. The criminal is not, or the prisoner is not, able to be conceived of as human. That's what I'm interested inthose kinds of normative as well as historical material structures that are making it difficult for us to make an argument for abolition. I'm also interested in those moments when we do succeed in demonstrating our fundamental co-dependence, including on those who we currently incarcerate, and the way that that kind of argument opens up opportunities for a better world to emerge.

WT

Thank you very much to the three of you for making time available for the readers of Counterfutures. 
If you like what you have read, please subscribe or donate.

\author{
G \\ COUNTERF UTURES \\ Left thought \& practice Aotearoa \\ (C) Copyright Counterfutures 2017
}

